\title{
Implementation and Effectiveness of Use The Character Education Instruments at Universitas Negeri Medan
}

\author{
Sahat Siagian $^{1 *}$, Hariadi $^{2}$, Pardomuan Nauli Josip Mario Sinambela ${ }^{3}$ \\ ${ }^{1)}$ Faculty of Engineering Universitas Negeri Medan, Indonesia \\ ${ }^{2)}$ Faculty of Sport Science Universitas Negeri Medan, Indonesia \\ ${ }^{3)}$ Mathematics Department Universitas Negeri Medan, Indonesia \\ *sahat.sgn61@gmail.com
}

\begin{abstract}
This study aims to determine the implementation and effectiveness of character education assessment instruments at Universitas Negeri Medan. The level of implementation achievement using interview and observation related to implementers' resources, implementers' attitude, communication between implementing organizations, Interviews and observations were conducted on 233 lecturers at the Unimed as respondents that using character education assessment instruments. The results of interviews and observations showed that respondents' understanding of character assessment instruments constraints and external support in the very good category (92.3\%), respondents' knowledge of the use of character education assessment instruments in the very good category $(94.7 \%)$. The response of the implementers showed accepting $96.5 \%$ while the rest showed a neutral response, and no one rejected the implementation of this character assessment instrument. Communication between related organizations (faculty commission and lecturer) in the excellent category (87\%). The intensity of the use of character education instruments by respondents was in the very frequent category (91.6\%). The implementation of this character assessment instrument does not face significant obstacles and has positive support from parties related to the implementation of this character education instrument. The effectiveness test conducted by giving questionnaires to the respondent shows that the character assessment instrument is easy to understand (94.5\%), easy to use $(96.2 \%)$, efficient $(95.2 \%)$, on target $(92.5 \%)$ as well as being following the objectives of the assessment $(95.3 \%)$. Thus, it can be concluded that this character education assessment instrument can be widely used in the learning process at Unimed.
\end{abstract}

Keywords: implementation, effectiveness, character Education, assessment instruments

\section{Introduction}

Universitas Negeri Medan (Unimed) as the character building university takes part to implement the character education in daily academic life in university. All of the elements of Unimed together to push the conducive atmosphere. To success this goal through the development of activity programs to increase the existence and image of Unimed.

The components to build character are hard skills and soft skills. Habituation of a good character at Unimed is expected to create a conducive academic situation to get the goal of character education. The implementation of character at Unimed is done through the integration of the curriculum. It's mean the role have learned by students with learning of the subject. 


\section{A. Research Focus}

Character is a way of thinking and behaving that characterizes each individual to live and work together, both within the family, community, and country. This research focus of the study is the effectiveness and implementation of the assessment instrument for the implementation of the six pillars of character announced by Unimed by lecturers in learning. The six pillars of character include (1) Trustworthiness, (2) Fairness, (3) Caring, (4) Respect (5) Citizenship and (6) Responsibility

\section{B. Formulation of Problem}

The instrument development effort has met the standard instrument criteria. However, the implementation and effectiveness of the use of these instruments are still unknown. The formulation of problem in this study are: How is the implementation and effectiveness of the instrument of character assessment by learning at Unimed?

C. Benefit of Research

1) $\mathrm{Be}$ an input for policymakers to determine the level of achievement of the implementation of character education instruments in learning at Unimed.

2) Determine the level of effectiveness of the use of character education instruments in learning at Unimed

\section{Concept of Character Education Variables}

In this section, we will discuss concepts related to this research variable, including describing ideas about the six pillars of character consisting of honesty, respect, fairness, responsibility, caring and citizenship, and learning to consist of planning learning, learning process, and learning assessment.

A child learns characteristics even before they start school [1]. When there is a conflict between family values and the environment or place of learning, and inner turmoil will arise in the child [2]. This means that synchronization between the family, the environment and educational institutions must be created. Thus, in the scope of formal education such as in tertiary institutions, there must be models of right attitude shown by all academicians

The intelligence contained in an individual includes the realm of intellectual knowledge, spiritual intelligence, and emotional intelligence. Spiritual knowledge and emotional intelligence are the means to grow the roots of one's character [3]. Intellectual knowledge will automatically be isolated if it is not supported by the other two bits of intelligence. Knowledge can be divided into six bits of intelligence [4], namely spiritual intelligence, physical knowledge, mental intelligence, emotional intelligence, social intelligence, and career intelligence. In more detail, these bits of intelligence can be associated with the pillars of character education. There are many sources that describe the pillars of character education, but in the Unimed, environment, refer to the six pillars [5] which can be stated as:

1) Trustworthiness. This first pillar contains the following elements: a) Honesty, which reflects an unwillingness to lie, cheat, or steal; b) Reliability, which includes the fulfillment of commitments, compliance with rules and a binding code of ethics; c) courage to act based on truth; d) building a good reputation, and e) loyalty [2]

2) Respect. The components of character building are : a) respecting and treating others with respect; b) tolerate and accept differences; c) behave well and avoid harsh words; d) consider the feelings of others; e) not threatening, hitting or injuring others; and f) retaining anger, not insulting others, and not forcing disapproval on others [2].

3) To be responsible. Responsibility is understood in a number of perspectives such as carrying out obligations, making plans, being tough, trying to do the best, self-control, 
discipline, thinking before acting, being responsible for words, deeds, and attitudes, and being an example to others [2].

4) Fairness. The definition of fairness is the willingness to act fairly for oneself and others [2]. This fair action is indicated by the willingness to follow the rules of the game, providing opportunities for oneself and others, being open-minded (willing to listen to others), not using others, not blaming others arbitrarily, and treating others fairly[6] .

5) Caring, Real care is marked by hospitality / kindness, sympathy and empathy, gratitude, willingness to forgive others, and help people who are in need [2].

6) Citizenship. The values of this sense of unity are manifested in the form of tangible contributions to make the community where he is better, cooperate with others, engage in community activities, keep abreast of information developments, be a useful member of society, obey laws and legislation, respect leaders, care for the environment, and volunteerism [7].

\section{Instrument Implementation Policy}

Referring to the theory by Van Metter and Van Horn [8], it is stated that the implementation process is an abstraction or performance of a policy embodiment, which is done to achieve high policy implementation performance and takes place in the relationship of various variables. Several interrelated variables influence policy performances, these variables, namely:1) Policy standards and objectives/measures and policy objectives, 2) Resources, 3) Characteristics of implementing organizations, 4) The attitude of the lecturers, 5) Communication between related organizations and implementation activities, 6) Social, economic and political environment.

In detail the variables of the implementation of the Van Meter and Van Horn [8] public policy models are explained as follows:

1) Policy standards and objectives / measures and policy objectives

The performance of policy implementation can be measured by the level of success of the size and objectives of policies that are realistic with the socio-culture at the policy implementation level. Understanding the general purpose of standard and policy objectives is also very important [9]. The implementation of the use of this instrument can be successful; it may fail when the lecturers as the implementers are not fully aware of the standards and objectives of the policy, failure can also be because they reject or do not understand what the goal of a system is.

2) Resources

The success of policy implementation depends on the ability to utilize available resources. Each stage of implementation requires quality human resources following the work needed by apolitically determined policies. In addition to human resources, financial and time resources become essential calculations in the successful implementation of policies.

3) Characteristics of implementing organizations

The performance of policy implementation will be significantly influenced by the right characteristics and matches with the implementing agencies. This relates to the policy context that will be implemented in several policies that are required to apply strict and disciplined policies. In other settings, a democratic and persuasive implementing agent is needed.

4) Communication between related organizations and implementation activities Standards of policy objectives must be understood by the implementers responsible for achieving the policy standards and goals, therefore standards and objectives must be 
communicated to implementers. Communication delivering information to policy implementers about what are the rules and objectives must be consistency and uniformity from various sources of information. If there is no clarity and consistency and uniformity towards a standard and policy objective, then what becomes the standard and policy objective is difficult to achieve [10].

\section{Disposition or attitude of implementers}

In the opinion of Van Metter and Van Horn [11], the attitude of acceptance or rejection of the agent implementing the policy dramatically affects the success or failure of the implementation of public policy. Good acceptance of standards and policy objectives among those responsible for implementing the policy is an excellent potential for the successful implementation of the system [12]

\section{Social, economic and political environment}

The last thing to consider in assessing the performance of policy implementation is the extent to which the external environment contributes to the success of the public policy. By utilizing these concepts, the problems that need to be examined in this connection are: 1) What are the obstacles in introducing change in the organization, 2) As far as the level of effectiveness of the control mechanisms at each level of the structure is concerned, this problem concerns the power of the lowest party in the organization concerned, 3) How important is the attachment to each person in the organization. Policy implementation is a crucial stage in the public policy process. A policy program must be implemented so that it has an impact or can achieve the desired goals [13]. Implementation study is a study of policy studies that lead to the implementation process of policy. Implementation of policies, in principle, is a way for a system to achieve its objectives.

Meanwhile, Grindle [14] also gave his view on implementation by saying that, in general, the task of the application is to form a linkage that facilitates policy objectives can be realized as the impact of government activity.

\section{Research Method}

Basically, this research is motivated by the question of whether the implementation of character education in learning has been done well by lecturers in the Unimed environment. To answer these questions, a set of instruments has been developed to assess character education in learning. This study aims to determine the level of success of the instrument implementation in learning as well as to determine the effectiveness of the instrument in assessing character education in learning at Unimed.

1) Research Stages

This research is a study that combines qualitative and quantitative research methods. This combination is expected to provide benefits, including sharper validity, stronger results, and broader horizons. Qualitative research is used to assess the successful implementation of character assessment instruments at Unimed. The stages carried out are as follows:

2) Material Socialization \& Preparation

The socialization was carried out to provide information and fundamental knowledge regarding the instrument of character education assessment that had been developed previously. The socialization was given to the Chairpersons and Secretaries of the Departments / Study Programs and all lecturers in the Unimed. In this socialization, it is 
expected that the lecturers, as users can use the instruments that have been developed in each course they teach. The preparation of the material is intended to carry out the editing, layout, and print process of the instrument that has been developed. This stage is intended to provide ease of use, value processing, and reporting of assessment results using instruments that have been developed. The printed instruments will be given to the lecturers to be used in the learning of the courses they teach.

3) Implementation phase

At the implementation stage, the study was conducted qualitatively using interview guidelines and observation guidelines. The results obtained are interpreted to assess the successful implementation of the use of character assessment instruments in learning in the Unimed environment. Things that can be observed in the implementation of the use of character assessment instruments include: 1) Resources, 2) Characteristics of implementing organizations, 3) The attitude of the implementers, 4) Communication between related organizations and implementation activities, 5) Social, economic and political environment

4) Test the effectiveness of the instrument

Testing the effectiveness of the character education assessment instrument is done by using a questionnaire given to the organization implementing the assessment, in this case, lecturers in the Unimed environment. The survey given was a closed questionnaire using a Likert scale of $1-5$ by eliminating the number 3 to avoid hesitant answers from respondents. The questions or statements one listed in the survey contain variables testing the effectiveness of the use of the instrument, including aspects of acceptability, relevance, sensitivity, reliability, and practicality of the device.

5) Research design

The implementation research design and effectiveness of character education assessment instruments generally consist of three main stages, namely socialization, implementation and effectiveness test.

\section{Results and Discussion}

\section{Material Socialization \& Preparation}

The socialization was carried out to provide uniform understanding and knowledge in using this instrument. The socialization to the Chairmen and Secretaries of the Circus within the Unimed was held on Thursday, July 8, 2019 at the Unimed Multipurpose VIP Room. The preparation of the material is intended to carry out the editing, lay-out and print processes on the instruments that have been developed.

\section{Implementation phase}

At the implementation stage, the study was conducted qualitatively using interview guidelines and observation guidelines. Things that can be observed in the application of the use of this character assessment instrument include implementing resources, characteristics of the implementing organization, the attitude of the Lecturers, communication between related organizations and implementation activities, and the social, economic, and political environment.

1) Resources

Resources needed in the implementation of character education assessment instruments in learning at Unimed are human resources in the form of lecturers as competent instructors, time resources in the form of socialization about character education 
assessment instruments, financial resources in the form of funds needed to support the process of implementing assessment instruments character building.Judging from the qualifications of lecturers as educators at Unimed in terms of lecturer education can be seen from Table I, following:

Table 1. Qualification of Lectures at Unimed

\begin{tabular}{|c|c|c|c|c|c|c|}
\hline \multirow{2}{*}{ No } & \multirow{2}{*}{ Faculty } & \multirow{2}{*}{$\begin{array}{c}\text { Number } \\
\text { of } \\
\text { Lecture }\end{array}$} & \multicolumn{4}{|c|}{ Degree } \\
\hline & & & Doctoral & $\%$ & Master & $\%$ \\
\hline 1 & faculty of Language and Art & 176 & 43 & 24.43 & 133 & 75.57 \\
\hline 2 & faculty of Economics & 117 & 13 & 11.11 & 104 & 88.89 \\
\hline 3 & faculty of Sport Science & 78 & 16 & 20.51 & 62 & 79.49 \\
\hline 4 & faculty of Education & 79 & 24 & 30.38 & 55 & 69.62 \\
\hline 5 & Faculty of Social Science & 89 & 23 & 25.84 & 66 & 74.16 \\
\hline 6 & $\begin{array}{l}\text { Faculty of Mathematics and } \\
\text { Natural Sciences }\end{array}$ & 221 & 69 & 31.22 & 152 & 68.78 \\
\hline \multirow[t]{2}{*}{7} & Faculty of Engineering & 146 & 34 & 23.29 & 112 & 76.71 \\
\hline & Average & & & 23.83 & & 76.18 \\
\hline
\end{tabular}

From Table 4.1 it can be seen that all lecturers have taken master's level education with an average of $23.8 \%$ having completed the doctoral level. In terms of educational qualifications, it can be stated that the socialization for the uniformity of knowledge and understanding of the implementation of character education assessment instruments in the teaching of the lecturers did not experience significant obstacles. At the time of the socialization there were many inputs given by the lecturers to improve the instruments that would be used primarily for practical use. In connection with the socialization time resources carried out at the beginning of lectures in odd semester 2019-2020, namely on Monday, July 22, 2019 to Tuesday, July 30, 2019 at their respective faculties. In addition to being carried out collectively, socialization is also carried out by forming small discussion groups at the department or study program level to facilitate the understanding of lecturers as implementing agents. Small discussion groups are conducted with the help of lecturers to become peer tutors for their circles.

2) Characteristics of Implementing Agencies.

The performance of policy implementation will be very much influenced by the right characteristics and suitable with the agents of its implementation. The agents of implementation in the implementation of the character education assessment instrument are lecturers in the Unimed environment. Of the 233 respondents taken randomly in this study, research was conducted on the Semester Learning Plan (RPS) and Lecture Events Unit (SAP) to see character education integrated in the RPS and SAP. The character education integrated in the RPS and SAP is expected to be able to use the character education assessment instruments that have been prepared to obtain more accurate and objective assessment results. The results of RPS and SAP searches that have been compiled by the lecturers selected as samples can be seen in Table II. 
Table 2. The Result Of Rps And Sap

\begin{tabular}{|c|c|c|c|c|c|c|c|}
\hline \multirow[t]{2}{*}{ No } & \multirow{2}{*}{ Faculty } & \multirow{2}{*}{$\begin{array}{c}\text { Number } \\
\text { of } \\
\text { Lecturer }\end{array}$} & \multirow{2}{*}{$\begin{array}{c}\text { Number } \\
\text { of } \\
\text { Sample }\end{array}$} & \multicolumn{4}{|c|}{$\begin{array}{l}\text { The Implementation of } \\
\text { Character }\end{array}$} \\
\hline & & & & RPS & $\%$ & SAP & $\%$ \\
\hline 1 & Faculty of Language and Art & 179 & 39 & 37 & 94.87 & 36 & 92.31 \\
\hline 2 & Faculty of Economics & 116 & 32 & 30 & 93.75 & 31 & 96.88 \\
\hline 3 & Faculty of Sport Science & 82 & 21 & 19 & 90.48 & 20 & 95.24 \\
\hline 4 & Faculty of Education & 79 & 22 & 21 & 95.45 & 20 & 90.91 \\
\hline 5 & Faculty of Social Science & 89 & 26 & 25 & 96.15 & 25 & 96.15 \\
\hline 6 & $\begin{array}{l}\text { Faculty of Mathematics and } \\
\text { Natural Sciences }\end{array}$ & 221 & 60 & 58 & 96.67 & 55 & 91.67 \\
\hline \multirow[t]{2}{*}{7} & Faculty of Engineering & 146 & 33 & 30 & 90.91 & 31 & 93.94 \\
\hline & Average & & & & 93,49 & & 93,87 \\
\hline
\end{tabular}

3) Disposition of Implementers.

Variables assessed in the attitudes and tendencies of the lecturers include cognition, understanding and comprehension, and understanding of policy; the direction of the responses of lecturers whether accepting, neutral or rejecting, and the intensity of the use of character education instruments. The results of the questionnaire and interviews regarding the knowledge of the respondents in using this character education assessment instrument showed 163 people in the Very Good category, 50 people in the Good category, and 20 people in the Good Enough categories. It can be concluded that the knowledge of the respondents was $92.4 \%$ and categorized Very Good. For the understanding of the respondents obtained 190 people in the Very Good category, 25 people in the Good category, and 13 people in the Fairly Good category. Thus it can be concluded that the understanding of the respondents was $94.7 \%$ and included in the category of Very Good. A total of 225 people $(96.5 \%)$ of respondents chose the attitude of acceptance. It would use the socialized character education assessment instrument, while the rest ( 8 people) were neutral, and none of the respondents chose the attitude of refusing the use of this character education assessment instrument, intensity of use educational assessment instruments in learning are also very frequent $(91.6 \%)$, the respondents use it almost in every learning in the course they teach.

4) Communication between Organizations and Implementing Activities.

The parties involved in the organization implementing the implementation of character education instruments include the Chairperson / Secretary of the Department / Study Program, Lecturer Supporting Subjects as executors, and students as objects that are assessed in character education instruments. The results of observation show that communication between departmental functionaries (Chairperson and Department Secretary) and lecturers supporting subjects is very good. Departments/study programs, in general, provide the facilities needed by the lecturers as respondents in this study. There are several major's / study programs that facilitate the formation of special discussion groups for the assessment of character education. In conducting an evaluation, 
respondents generally communicate the use of instruments to students as objects of assessment so that they are expected to display the best characters they have.

\section{5) Economic, Social and Political Environment}

Observations and interviews will be conducted to see the extent to which the external environment has contributed to the success of established public policies. The nonconducive social, economic, and political situation can be the failure of the implementation of this character education instrument. Observation and interview results show that, according to the respondents, the current economic, social, and political environment at Unimed provides positive support for the development and cultivation of character education for students. The salaries and allowances received by lecturers are considered sufficient to give economic peace to the respondents, including even young lecturers. The family atmosphere that is built up among the lecturers fosters a communicative and mutually supportive social environment to achieve the highest achievements. According to the respondents, the political climate at Unimed is currently in a conducive condition so that the implementation of character education assessment instruments can be carried out without significant obstacles.

6) Instrument Effectiveness Test.

Testing the effectiveness of character education assessment instruments is done by using a questionnaire. The questions or statements listed in the questionnaire contain the test variables for the effectiveness of the use of the instrument, including aspects of convenience, efficiency, accuracy, and compliance with the purpose of the assessment. This effectiveness test is being carried out by distributing questionnaires to samples that are learning through character education assessment instruments.

\section{Conclusion}

The conclusions obtained from the research on the implementation of instruments of character education assessment include:

Human resources in the implementation of the character education assessment instrument have characteristics with a minimum education qualification of a master so that they can use instruments with a high level of knowledge and understanding of the instruments used.

Lecturers at Unimed as the implementing agent for the implementation of character education assessment instruments have included character education in the semester learning plan with an average of $93.43 \%$.

The results of the socialization and interview show good acceptance from the agents implementing the use of this character education assessment instrument with widespread usage intensity $(91.6 \%)$.

The results of interviews with the sample as an informant showed that communication between departmental functionaries with lecturers supporting subjects was excellent.

The results of interviews with the sample as informants show the economic, social, and political environment at Unimed is very good to support the implementation of this character education assessment instrument in learning at Unimed.

\section{References}

[1] Diane Tatun. (2010). Character Education and Behavior in Public Schools. Retrieved of http://www.suite101.com. 
[2] Doni Koesoema A. (2007). Pendidikan Karakter: Strategi Mendiidk Anak di Zaman Global. Jakarta: Grasindo.

[3] Arthur James. (2019). The Formation of Character in Education. London: Routledge.

[4] Thomas Lickona. (2012). Character Matters. Jakarta: Bumi Aksara.

[5] Kiesa D Brenneman, (2009). Tes IQ: Untuk Mengembangkan Kecakapan Menghadapi Hidup. Las Vegas: Putman \& Putman.

[6] Marc R. Major, (2008). The Teacher's Survival Guide: Real Classroom Dilemmas and Practical Solutions. Maryland: Rowman \& Littlefield Education.

[7] Tutuk Ningsih. (2015). Implementasi Pendiidkan Karakter. Purwokerto: STAIN Press.

[8] Budi Winarno. (2002). Kebijakan Publik, Teori dan Proses. Yogyakarta: Media Presindo.

[9] Riant Nugroho. (2008). Kebijakan Publik: Formulasi, Implementasi dan Evaluasi. Jakarta: PT. Elex Media Komputindo.

[10] Miftah Thoha. (2008). Ilmu Administrasi Publik Kontemporer. Jakarta: Kencana.

[11] Joko Widodo. (2001). Good governance. Telaah dari Dimensi Akuntabilitas dan Kontrol Birokrasi pada Era Desentralisasi dan Otonomi Daerah. Surabaya: Penerbit Insan Cendekia.

[12] AG Suharsono. (2005). Kebijakan Publik: Konsep, Teori dan Aplikasi. Yogyakarta: Pustaka Pelajar.

[13] Abdul Solichin Wahab. (2008). Analisis Kebijakan: Dari Formulasi ke Implementasi Kebijaksanaan Negara. Jakarta: PT. Bumi Aksara.

[14] Leo Agustino. (2014). Dasar-Dasar Kebijakan Publik. Bandung: Alfabeta. 